\title{
Effect of Psychoeducation Intervention on Self-efficacy and Coping of Adolescent Thalassemic Survivors in Indonesia
}

\author{
Henny Suzana Mediani ${ }^{1}$, Risnawaty ${ }^{2} \&$ Ai Mardhiyah ${ }^{1}$ \\ ${ }^{1}$ Department of Pediatric Nursing, Faculty of Nursing, Universitas Padjadjaran, Indonesia \\ ${ }^{2}$ Master of Nursing Student, Faculty of Nursing, Universitas Padjadjaran, Indonesia \\ Correspondence: Henny Suzana Mediani, Faculty of Nursing, Universitas Padjadjatran, Jl Raya Bandung \\ Sumedang Km 21, Jatinangor, Sumedang, 45363, West Java, Indonesia. Tel: 62-22-779-6647.
}

\author{
Received: January 7, 2021 Accepted: March 4, 2021 Online Published: March 15, 2021 \\ doi:10.5539/gjhs.v13n4p124 \\ URL: https://doi.org/10.5539/gjhs.v13n4p124
}

\begin{abstract}
Thalassemia is a chronic illness with having serious psychological challenges for adolescent thalassemic survivors. Many experienced problematic issues with their self-efficacy and coping as impacts of the disease and its treatments. Although thalassemia is a major health problem in Indonesia that challenges health care professionals to improve adolescent thalassemic survivors' quality of life, no studies have been undertaken to improve self-efficacy and coping of those adolescents with thalassemia by using psycho-education. This research aim was to examine the effect of psycho-education on self-efficacy and coping of adolescents with thalassemia. The study was conducted in two hospitals in Garut, Indonesia. The research method used was quasi-experiment with the pre-post test without the control group. The participants were thalassemic adolescent survivors aged 12-18 years old with 48 determined by total sampling technique. All participants received the psycho-education intervention with lecturing and booklet. Participants' self-efficacy was measured with the Chronic Disease Self-Efficacy Scales (CDSES), and their coping was measured with the Ways of Coping (WOC) Scale. The collected data were analized by using the Shapiro-Wilks to test for normality and the Wilcoxon test. The results showed there was meaningful difference with self-efficacy before and after intervention $(\mathrm{p}<0,001)$, and meaningful difference on adolescent thalassemic survivors'coping before and after intervention $(\mathrm{p}=0,004)$. It can be concluded that there was a significant effect of psycho-education on self-efficacy and coping of those adolescent thalassemic survivors. Therefore, it is recommended that the psycho-education intervention can be used as one of nursing intervention for enhancing self-efficacy and coping of adolescents with major thalassemia.
\end{abstract}

Keywords: Adolescents, coping, psycho-education, self-efficacy, thalassemia major

\section{Introduction}

Thalassemia is a genetic disorder in red blood cells inherited autosomal recessively which is caused by abnormal hemoglobin production characterized by the complete absence or reduced synthesis of the alpha-or-beta-globin chain of hemoglobin (Mediani, Tiara, \& Mardhiyah., 2019; Madderom et al., 2016). The World Bank (2016) states that $7 \%$ of total world population is carrying thalassemia with them. Each year, around 300.000-500.000 newborn babies carry severe hemoglobin disorders, and 50.000-100.000 children die from thalassemia. Eighty percent of those sufferers and casualties are from developing countries. Indonesia is one of those countries located on the world thalassemia belt, meaning countries with high gene frequency (number carrying characteristic) of thalassemia. Earlier studies conducted in Indonesia noted that 3-10\% of Indonesian citizens carries thalassemia gene because of the abnormal hemoglobin production (Mediani et al., 2017; Mediani, Tiara, \& Mardhiyah, 2019).

Data from the Association of Indonesian Thalassemia Foundation records (2016) noted that in 2006 there were about 3.053 cases of thalassemia and in 2008 the number increased into 5000. Meanwhile, in 2015 the cases of thalassemia major reached to 7,029 cases. Among those thalassemic survivors came from West Java elevated significantly in number from 1.700 patients of thalassemia in 2010 becoming 2.043 in two years (Maghfiroh, Okatiranti, \& Sitorus, 2014). Thalassemia major cases kept increasing in 2017 as many as 8.616 cases in Indonesia. West Java province is known as high number with 3.264 of thalassemia survivors in 2017. This indicated that West Java has $42 \%$ of total national thalassemia cases and ranked the highest for thalassemia survivors in Indonesia (Ministry of Health Indonesia, 2017). According to medical record of Garut Distric hospital West Java, on January 2013 there were as many as 230 thalassemic survivors come to Hemato-Onkologi clinic. Out of that number, 162 
patients or 70\% were adolescent thalassemic survivors (aged 14-21 years old) (Maghfiroh et al., 2014). Thallasemia is clearly a public concern in Indonesia that needs to be managed optimally.

Thalassemia for several Southeast Asia countries including Indonesia is major public problem not only for the thalassemic survivors and their families but also for the Public Health System due to the cost of treatment involving regular transfusions, iron chelation therapy, frequent hospitalization and general medical follow up (Mediani, Tiara, \& Mardhiyah, 2019; Mediani et al., 2017).

Thalassemia is a chronic illness that presents a range of serious clinical problems and psychological challenges. Thalassemia gives physical health impacts that can lead to physical deformity, growth retardation, and delayed puberty (De Sanctis et al., 2006, Mediani, Tiara, \& Mardhiyah., 2019). Thalassemia can cause a physical and psychosocial effect on adolescent thalassemic survivors, such as feeling different from their peers, feeling their activities being limited, experiencing social isolation, being insecure, feeling anxiety with their unwell condition, having high temperament, feeling under pressure, and terrible social function of the school, feeling guilty, denial, and excessive protection (Atiay, 2008; Thiru et al., 2016; Hockenberry \& Wilson, 2015; Hashemi et al., 2015; Anie \& Massaglia, 2005; Anggororini et al., 2010). The psychological problems of adolescent thalassemic survivors may also affect their quality of life.

An earlier study conducted by Tejaningsih (2018) in Garut West Java indicated that self-efficacy of thalassemic adolescent survivors who are burdened with thalassemia major falls in the medium category (with mean 70,0). Adolescents who suffer from major thalassemia need adequate self-efficacy to help them overcoming and responding to stressors as a consequence of having major thalassemia illness. With having high self-efficacy, adolescents with chronic illness are capable of overcoming social, psychological, and physical obstacles so that it will also influence the effectiveness of their therapy and provide them bigger faith in their abilities to handle daily tasks better and do actions to reach their goals (Adegbola, 2011; Huang et al., 2013). Adolescents suffering from thalassemia experience psychological crisis such as stress, losing control due to different from peers and it requires coping strategies. Coping strategies are mechanisms which people tolerate and mimimize or mitigate adverse effects of stressful events. Effective coping strategies are useful to reduce stress and psychological problems caused by chronic illness (Anie, 2005; Hashemi et al., 2015).

The literature identifies that there are several interventions that can be carried out by nurses to improve the self-efficacy of adolescents who suffer from thalassemia. Home-care training can develop thalassemia patients' self-efficacy; there is an increasing mean of self-efficacy after an intervention is accomplished (Moghadam et al., 2016). The rate of self-efficacy of those people with thalassemia also significantly advances after the intervention of self- management programs (Ahmadi, Shariati, Jahani, Tabesh, \& Keikhaei, 2014). The formation of Group Medical Appointments (GMA) also positively affects self-efficacy and obedience on children and adolescents with thalassemia (Madderom et al., 2016).

Another intervention that can be conducted to progress the coping of thalassemic adolescents is coping strategies training. Coping strategies training has been developed by using focused coping strategies on problems and effectively dealing with stress and other disease-related problems of those patients with major thalassemia (Hashemi, Sharif, Karimi, Hemophilia, \& Zare, 2015). Bandura (1977) revealed that the role of cognitive processes in social learning theory and focus on self-efficacy as an antecedent factor of behavior change. A study found that a psycho-education program is effective in enhancing self-efficacy in patients with chronic illness (Cheng \& Chan, 2005). Psycho-education on adolescents' thalassemia survivors is used to improve knowledge and handle psychosocial problems so that they gain positive self-efficacy and coping to deal with their existing problems (Anie, 2005). According to the theory of Health Promotion Model (HPM) by Pender (1996) which states that psycho-education can improve someone's health rate through empowerment attempt with health promotion. Pender's health promotion model (HPM) is known and widely used to change unhealthy behaviors. However, to this present, researchers have not figured out research that investigates the correlation between psycho-education intervention, and self-efficacy and coping of adolescents thalassemic survivors both in Indonesia and aboard. Based on the explanation above and the urgent need for information by thalassemic adolescent survivors, the researchers were interested in identifying the effect of psycho-education on self-efficacy and coping of adolescents who struggle with major thalassemia Garut District West Java.

\section{Methods}

\subsection{Research Design}

This study used a quasi experiment method with pre-post test without control group design. 


\subsection{Setting and Sampling}

This study was accomplished in 4 weeks from April 3 - May 3, 2019. The study was conducted at a 26-bed of thalassemia clinic unit in dr. Slamet hospital Garut and 22-bed of hemato-oncology clinic Guntur hospital Garut West Java province. The hospitals are referral hospitals in Garut. From the monthly record in October 2018, 164 thalassemia patients visited Thalassemia clinics in two hospitals in Garut, with 28 of whom were adolescents aged 12-18 years old. A total of 48 adolescent thalassemic survivors were asked to participate in the study. The adolescents thalassemic survivors and their parents signed the consent forms. The population of adolescents thalassemic survivors sampling technique used is total sampling.

\subsection{Data Collection}

\subsubsection{Data Demographic}

Demogrphic data such as age, sex, and education level were collected from the adolescent thalassemic survivor participants.

\subsubsection{Self-Efficacy}

Chronic Disease Self-Efficacy Scale (SCDSES) was used to analyze adolescent thalassemic survivors' self -efficacy. The scale consists of 33 items. The instrument has been validated and tested for its reliability to adolescents with thalassemia major in Indonesia with a coefficient test result of $\alpha$ as much as 0,942 (Tejaningsih, 2018). Alternative answers range from 1-10. A higher score indicates better self-efficacy (Lorig et al., 1996). To gain ease in univariate interpretation, the average score of self-efficacy is converted into score ranging from 0-100 and are then categorized into the following provision: very low $=<60$; low $=60-68$; medium $=69-76$; high $=77-84$, very high $\geq 85$

\subsubsection{Coping}

Ways of Coping Scale (WOC) questionnaires by Folkman and Lazarus (1986) was used to measure coping of adolesecnts thalassemic survivors. The scale is consisted of 66 items in Likert scales. The score was given between 0-3, with (0) means never (never commit to the activity), (1) sometimes (3-4 times during stress/anxiety), (2) often (twice during stress/anxiety), (3) always (each time experiencing stress/anxiety). The score of WOC might range between 0-198. Validity and reliability test conducted with result in Alpha Cronbach value was as much as 0,992 $(>0,7)$ and value of $r>0,444$ meaning that all items in research instrument were reliable and creditable to be used in this study.

\subsubsection{Procedure}

Psycho-education intervention in this study was given to adolesecent participants through health educating activities divided into two sessions. Psycho-education intervention was actualized using lecturing, discussion, and demonstration method in small groups. The first session was sharing information related to thalassemia and the second one deals with ways to improve adolescent thalassemic suvivors' self-efficacy and coping. On the approved day, participants filled informed consent and participated in pre-test. It was continued with psycho-education intervention session I namely delivering information about thalassemia. Psycho-education Intervention was attended by all participants. The researcher divided time for administrating the intervention into four groups (two groups for each hospital). Each participant was given freedom to choose a group which group to join during the psychoeducation intervention conducted.

All participants were given booklet during the psycho-education intervention performed. The researchers shared the information using power point presentation media for about 30-45 minutes with 15 minutes for material session and 15-20 minutes for discussion session. After session I, participants took a break for 15 minutes and then followed by session II. In session II, participants received intervention about self-efficacy and coping strategies training in facing problems ( \pm 60 minutes). After the whole psycho-education activities were accomplished, participants were asked to took the booklets to be learned and become participants' belonging. Post-test assessment was done in 18-23 days after the intervention and was carried out on participants' schedule of blood transfusion.

\subsection{Data Analysis}

Univariate analysis in this study includes participants' data demography while bivariate analysis was performed to identify the effect of independent variable (psycho-education) on dependent variable (adolescents' self-efficacy and coping). Data analysis was carried out after normality test with Shapiro-wilk. Wilcoxon statistic test was used to asses the impact of psycho-education on adolescents' self-efficacy and coping before and after intervention. 


\subsection{Ethical Consideration}

This study has been reviewed and granted ethic from Medical Research Ethic Committee Medical Faculty, Universitas Padjadjaran, Indonesia. It has also obtained research recommendation from Bureau of National Unity, Politics, and Society Protection Garut, West Java. The research permission letter was gain from dr. Slamet hospital Garut and Guntur hospital Garut.

\section{Results}

The following table displays data on demographic of participants (Table 1). Numeric data on age is presented in mean, standard deviation, and minimum-maximum scores. Meanwhile, categorical data of sex and education are shown in percentage.

Table 1. Frequency Distribution of participants' demographic data based on Age, Sex and Education Level in Garut Regency $(\mathrm{n}=48)$

\begin{tabular}{lllll}
\hline Variable & Mean \pm SD & Min-Max & N & \% \\
\hline Age & $14 \pm 2$ & $12-18$ & & \\
\hline Sex & & & & \\
& Male & & 29 & 60,4 \\
& Female & & 19 & 39,6 \\
\hline Education & & 21 & 43,8 \\
$\quad$ Primary Level & & 16 & 33,3 \\
& Junior High Level & & 11 & 22,9 \\
& Senior High Level & & 11 \\
\hline
\end{tabular}

Table 1 shows that the youngest age of all participants is 12 year and the oldest age is 18 year. Most of participants are male identified as many as 29 people $(60,4 \%)$. The majority of participants' education background on primary school level for as many as 21 people $(43,8 \%)$. In Table 2 below illustrated the effect psycho-education on thalassemic adolescents' self-efficacy.

Table 2. the effect of Psycho-education on Self-Efficacy of Teenagers with Major Thalassemia in Garut Regency Before and After Psycho-education Intervention $(\mathrm{n}=48)$

\begin{tabular}{llllll}
\hline \multirow{2}{*}{ Category } & \multicolumn{2}{c}{ Before Intervention } & \multicolumn{2}{c}{ After Intervention } & p-value \\
& $\mathrm{n}$ & $\%$ & $\mathrm{n}$ & $\%$ & \\
\hline Very Low $(<60)$ & 15 & 31,3 & 2 & 4,2 & \\
Low $(60-68)$ & 13 & 27,1 & 2 & 4,2 & $<0,001 *$ \\
Medium (69-76) & 13 & 27,1 & 11 & 22,9 & \\
High (77-84) & 7 & 14,6 & 28 & 58,3 & \\
Very High $(\geq 85)$ & 0 & 0,0 & 5 & 10,4 & \\
\hline
\end{tabular}

It can be seen from the Table 2 scores of adolescent thallassemic survivors' self-efficacy before intervention fall into categories of very low, low, and medium respectively for as much as $31,3 \%, 27,1 \%$ and $27,1 \%$. While, after following psycho-education intervention, there was a decrease becoming $4,2 \%, 4,2 \%$ and $22,9 \%$ respectively. On the other hand, adolescents' self-efficacy scores fall in categories of high and very high before intervention for 14,6\% and $0 \%$. Meanwhile, after psycho-education intervention was performed, there was an increase turning into 58,3\% and $10,4 \%$. It is therefore, results of the study showed that psycho-education intervention increased the self-efficacy scores of adolescent thallassemic survivors with the value of $p<0,001$.

Results of psycho-education intervention on coping of adolescent thalassemic survivors are illustrated in Table 3 below. 
Table 3. The effect of psycho-education intervention on coping of adolescents with major thalassemia in Garut hospitals before and after Psycho-education Intervention conducted $(n=48)$

\begin{tabular}{lllll}
\hline \multirow{2}{*}{ Psycho-education } & \multicolumn{2}{c}{ Coping Score } & p-value \\
\cline { 2 - 4 } & Mean & SD & Min - Max & $\mathbf{0 , 0 0 4 *}$ \\
\hline Before Intervention & 99 & 19 & $58-137$ & \\
After Intervention & 116 & 27 & $55-160$ & \\
\hline
\end{tabular}

Based on table 3 above, it is shown that coping score before intervention is 99 (SD: 19) ranging from 58 - 137, while coping score after intervention is 116 (SD: 27), ranging from $55-160$. Referring to the table, it can also be seen that $\mathrm{p}$ value is $\mathrm{p}=0,004(<0,001)$ meaning that there is a significant increase in coping score after intervention, or in other words psycho-education gives meaningful influence on adolescent thalassemic survivors' coping.

\section{Discussion}

Adolescents thalassemic survivors face various psychosocial problems related to their disease and its treatment (Anie \& Massaglia, 2015; Hockenberry \& Wilson, 2015; Hashemi et al., 2015). Many of them experienced stress, depression, shyness, and low QOL comparing to healthy adolescents (Behdani et al., 2015; Hashemi et al., 2015). It is well known that chronic illnesses have a psychological implication, which in adolescents have great importance and challenges (Behdani et al., 2015). Children and adolescents with major thalassemia are vulnerable to emotional and behavioral problems (Mediani et al., 2017). Adolescents suffering from major thalassemia experienced mutual crisis; they should not only adjust to the complementary tasks but also must able to overcome stress caused by their illness, including feeling different from peers, losing control, and fear of death (Masineinezhad et al., 2018). One of the most important modifiable ways for adolescent thalassemic survivors is self-efficacy (Masineinezhad et al., 2018; Parhiz et al., 2016). Adolescents with major thalassemia are able to cope with their illness and treatments if they have high self-efficacy (Masineinezhad et al., 2018). Adolescents will deal with full-of-pressure situation with confidence so that it can resist stressful reactions (Bandura, 1997).

A previous study conducted by Huang et al. (2013) found that adolescents with chronic illness who possess high self-efficacy had influence on the effectiveness of the therapy. Aligned with this finding Adegbola (2011) indicated that patients with higher self-efficacy perform better ability in handling daily tasks and doing stuff to reach goals. Cramn et al. (2013) also supported this fact, who affirm that self-efficacy is an important factor in facing challenges and demands emerging in chronic conditions so that adolescents can manage their stress and achieve quick recovery.

Results of statistic analysis of this present study by using Wilcoxon test, $\mathrm{p}$-value was obtained as much as $\mathrm{p}=0,004$ $(<0,001)$ on adolescents' coping score (Table 3$)$. This showed that psycho-education presents a meaningful impact on coping with suffering from major thalassemia at hospitals in Garut Indonesia. Findings of this research displayed that psycho-education intervention enhanced on self-efficacy and coping of adolescent thalassemic survivors with a value of $\mathrm{p}<0,001$. Psycho-education intervention is an educative and pragmatic approach focusing on improving patients' knowledge and understanding about the disease while at the same time giving psychological support (Stuart \& Laraia, 2005).

Adolescents with major thalassemia need to overcome the psychological pressure/crisis/stress as psychosocial consequence of their disease and apply preventive strategies in order to adapt themselves towards stressors by applying high coping strategies (Hashemi, Darshori, et al., 2015; Dahnil, Mardhiyah, \& Widianti., 2017) The ability to adapt and face the psychosocial problems and changes on thalassemic adolescents are highly correlated with individual coping and their ways in adaptation towards the impact of the disease which threatens their lives. This idea supports Anie's opinion (2005), saying that the depth of psychosocial impact on thalassemic adolescents is determined by coping strategies that they apply. In line with Prussien et al. (2018), who mentions that there is a correlation between cognitive function and coping and depression symptoms in children with thalassemia. To handle the psychological problems, high self-efficacy, and effective coping strategies are necessary. Self-efficacy and coping strategies are two factors influencing stress levels. Hashemi et al. (2015) support the finding stating that effective coping strategies can reduce stress and complication related to the disease.

Findings of this present study displayed the effect of psycho-education on self-efficacy and coping of adolescent thalassemic survivors struggling with major thalassemia after intervention with a value of $p<0,001$. This fact is likely caused by psycho-education intervention. Psycho-education intervention is an educative and pragmatic approach focusing on improving patients' knowledge and understanding about the disease while at the same time 
giving psychological support (Stuart \& Laraia, 2005). Self-efficacy and coping of adolescents with thalassemia major are formed by knowledge and understanding about the disease. Actions committed by thalassemic adolescent survivors come from their minds. The thoughts give directions for what actions to be done. The higher thalassemic adolescent survivors' knowledge and understanding of their disease are, the bigger the contribution on self-efficacy and coping formation is.

These research findings support previous research conducted by Shorey, Wai, Chan, Chong, and He. (2014), who state that psycho-education can improve the self-efficacy of mothers with postpartum primipara. Another previous studies also support the finding that self-efficacy of those DM type 1 sufferers (Grey et al., 2013) and DM type 2 sufferers (Huzaimah, 2016) can increase by receiving the psycho-education intervention. Grey et al., (2013) found that adolescents with DM type 1 have been lower perceived stress, more motivated and engaged in the process of taking responsibility for self-management. Meanwhile, Huzaimah (2016) identified that the adolescent DM 2 sufferers also tend to have a positive behavior to monitor blood glucose levels.

This research evidence is also confirmed by Kartikasari, Yosep, and Sriati (2017), who declares that psycho-education is proved to increase the self-efficacy of the family of schizophrenia patients. This research finding is also endorsed by previous research carried out by McBride (2012), who claims that psycho-education can assist coping strategies improvement of adolescents who suffer from depression (Zaini, 2014). The findings of this present study are also supported by Rachmaniah (2012), who identified that psycho-education provides an important role on coping strategies of those parents who have children with major thalassemia. Results of current evidence found that improving self-efficacy and coping of adolescents with thalassemia major can be done by several interventions of home-care training (Moghadam et al., 2016), self-management programs (Ahmadi et al., 2014), and Group Medical Appointments (GMA) formation (Madderom et al., 2016). Meanwhile, adolescents' coping strategies can also be enhanced through coping strategies training (Hashemi, Sharif, et al., 2015; Videback., 2008).

\section{Conclusion and Reccomendations}

In general, it can be concluded that the findings of this study proved the significant effect of a psycho-education intervention on self-efficacy and coping of those adolescents suffering from major thalassemia. It is, therefore, psycho-education is expected to be an alternative nursing intervention to enhance self-efficacy and coping of adolescents suffering from thalassemia major. Psycho-education programs should be conducted by nurses on a regular basis for adolescents with thalassemia major to alleviate their knowledge about the disease and cope with it. Nurses have a responsibility to help adolescent thalassemic survivors to improve their self-efficacy and coping by educating them about health through psycho-education intervention. Other interventions that can be developed are home-care training and coping strategies training. For the next research, an investigation on factors affecting self-efficacy and coping of adolescent thalassemic survivors who struggle with thalassemia can be carried out through mixed method approaches.

\section{Acknowledgments}

We gratefully thank the authorities in Garut district hospitals Indonesia and all the nursing staff in the thalassemia clinic, and also all the adolescent thalassemic survivors and their parents who participated and helped us in this study.

\section{Competing Interests Statement}

The authors declare that there are no competing or potential conflicts of interest.

\section{References}

Adegbola, M. (2011). Spirituality, Self-Efficacy, and Quality of Life among Adults with Sickle Cell Disease. Southern Online Journal of Nursing Research, 11(1), 5. Retrieved from http://www.pubmedcentral.nih.gov/articlerender.fcgi?artid=3137798\& tool=pmcentrez\&rendertype=abstract

Ahmadi, M., Shariati, A., Jahani, S., Tabesh, H., \& Keikhaei, B. (2014). The Effectiveness of Self-Management Programs on Self-Efficacy in Patients With Sickle Cell Disease. Jundishapur J Chronic Dis Care, 3(3). https://doi.org/10.5812/jjcdc.21702

Anie, K. A. (2005). Psychological complications in sickle cell disease. British Journal of Haematology, 129(6), 723-729. https://doi.org/10.1111/j.1365-2141.2005.05500.x

Anie, K., \& Massaglia, P. (2005). Psychological therapies for thalassaemia (Review). The Cochrane Database of Systematic Reviews, (3). https://doi.org/10.1002/14651858.CD002890.pub2.www.cochranelibrary.com 
Atiay, S. A. (2008). Assessment of Nurse 's Role Regarding Care of Children with $\beta$-Thalassemia.

Bandura, A. (1977). Self-efficacy: Toward a unifying theory of behavioral change. Psychological Review, 84(2), 19-215. https://doi.org/10.1037/0033-295X.84.2.191

Cheng, L. Y., \& Chan, S. (2005). Psychoeducation program for Chinese family carers of members with schizophrenia. Western Journal of Nursing Research, 27(5), 583-599.

Dahnil, F., Mardhiyah, A., \& Widianti, E. (2017). Kajian kebutuhan supportive care pada orang tua anak penderita talasemia. NurseLine Journal, 2(1), 1-10. Retrieved from https://media.neliti.com/media/publications/197104-ID-assessment-of-supportive-care-needs-in-p.p

Grey, M., Whittemore, R., Jeon, S., Murphy, K., Faulkner, M. S., \& Delamater, A. (2013). Internet Psycho-Education Programs Improve Outcomes in for YouthWith Type 1 Diabetes. Care.Diabetes journals.Org, 1-8. https://doi.org/10.2337/dc12-2199.

Hashemi, F., Darshori, A. N., Sharif, F., Naderi Darshori, A., Sharif, F., Karimi, M., \& Zare, N. (2015). Effect of Coping Strategies Training On Its Use by Thalassemia Major Adolescents : A Randomized Controlled Clinical Trial. International Journal of Community Based Nursing and Midwifery, 3(1), 67-74. Retrieved from

http://www.pubmedcentral.nih.gov/articlerender.fcgi?artid=4280559\&tool=pmcentrez\&rendertype=abstract

Hashemi, F., Sharif, F., Karimi, M., Hemophilia, I., \& Zare, N. (2015). Effect of Coping Strategies Training On Its Use by Thalassemia Major Adolescents: A Randomized Controlled Clinical Trial. IJCBNM, 3(March), 66-74.

Huang, L., Li, L., Zhang, Y., Li, H., Li, X., \& Wang, H. (2013). Self-Efficacy, Medication Adherence, and Quality of Life Among People Living With HIV in Hunan Province of China: A Questionnaire Survey. Journal of the Association of Nurses in AIDS Care, 24(2), 145-153. https://doi.org/10.1016/j.jana.2012.04.006

Huzaimah, N. (2016). Model Psikoedukasi untuk Meningkatkan Pemahaman dan Efikasi Diri Penderita Diabetes Mellitus Tipe2. Jurnal Kesehatan "Wiraraja Medika ,"19-26.

Kartikasari, R., Yosep, I., \& Sriati, A. (2017). Pengaruh Terapi Psikoedukasi Keluarga terhadap Self Efficacy Keluarga dan Sosial Okupasi Klien Schizophrenia. Jurnal Keperawatan Padjadjaran, 5(2), 123-135.

Madderom, M. J., Heijdra, J., Utens, E. M. W. J., Polinder, S., Rijneveld, A. W., \& Cnossen, M. H. (2016). A randomized controlled trial studying the effectiveness of group medical appointments on self-efficacy and adherence in sickle cell disease (TEAM study): study protocol. BMC Hematology, 16(1), 21. https://doi.org/10.1186/s12878-016-0058-4

Maghfiroh, R., Okatiranti, \& E. Sitorus, R. (2014). Gambaran Harga Diri Pasien Thalasemia Remaja (usia 14-21 tahun) di Klinik Hemato-Onkologi RSUP Dr. Hasan Sadikin Bandung. Jurnal Ilmu Keperawatan, 2, 130-137. Retrieved from http://ejournal.bsi.ac.id/assets/files/Jurnal KeperawatanVol. II No 2 September_2014_Riska Maghfiroh, Okatiranti, Ria_E_.Sitorus_130-137_.pdf

Masinaeinezhad, N., Abdollahimohammad, A., Bonjar, A., \& Allahyari, J. (2018): The Effect of Self-Care Education Based on Orem's Model on Self-Efficacy of patients with Beta Thalassemia Major. La Prensa Medica Argentina, 104 (4): 1-4

McBride, M. C. (2012). The effects of brief psychoeducation on adolescents' depressive symptoms and perceptions of parenting. Dissertation Abstracts International: Section B: The Sciences and Engineering, 72, 4989. https://doi.org/10.1017/CBO9781107415324.004

Mediani, H.S., Tiara, A., \& Mardhiyah, A. (2019). Factors Related to The Needs of Parents Having School Age

Thalassemic Children. Padjadjaran Nursing Journal (Jurnal Keperawatan Padjadjaran), vol 7(2), 173-187. doi : $10.24198 / \mathrm{jkp}$

Mediani, H. S., Nurhidayah, I., Mardhiyah, A., \& Panigoro, R. (2017). Indonesian mothers' needs and concerns about having a thalassemic child and its treatment: An exploratory qualitative study. International Journal of Nursing \& Care, 1(2), 1-7.

Moghadam, M. P., Nourisanchol, H., Shahdadi, H., Shahraki, S., Azarkish, B., \& Balouchi, A. (2016). Effects of Home-Care Training on The Self-Efficacy of Patients With Beta Thalassemia Major. Mater Sociomed, (August), 357-360. https://doi.org/10.5455/msm.2016.28.357-360

Parhiz, Z., Birjandi, M., Khazaie, T., \& Sharifzadeh, G. (2016): The Effects of an Empowerment Program on the 
Knowledge, Self-Efficacy, Self-Esteem, and Attitudes of Mothers of Preterm Neonstes. Modern Care Journal, $13(3): 1-5$

Pender, N. (1996). Health Promotion in nursing practice. $3^{\text {rd }} e d$. Stamford, CT: Appleton and Lange

Prussien, K. V, DeBaun, M. R., Yarboi, J., Bemis, H., McNally, C., Williams, E., \& Compas, B. E. (2018). Cognitive Function, Coping, and Depressive Symptoms in Children and Adolescents with Sickle Cell Disease. Journal of Pediatric Psychology, 43(5), 543-551. https://doi.org/10.1093/jpepsy/jsx141

Rachmaniah, D. (2012). Pengaruh Psikoedukasi Terhadap Kecemasan Dan Koping Orang Tua Dalam Merawat Anak Dengan Thalasemia Mayor DI RSU Kabupaten Tangerang Banten.

Shorey, S., Wai, S., Chan, C., Chong, Y. S., \& He, H. (2014). A randomized controlled trial of the effectiveness of a postnatal psychoeducation programme on self-efficacy, social support and postnatal depression among primiparas. Journal of Advanced Nursing, 71(6), 1260-1273. https://doi.org/10.1111/jan.12590

Stuart, G. W., \& Laraia, M. T. (2007). Principles and practice of psychiatric nursing (8th ed.). St. Louis: Mosby Year Book.

WHO. (2006). Disease Control Priorities in Developing Countries. $2^{\text {nd }}$ Ed. The World Bank 1818 H Street NW

Zaini, M. (2014). Manajemen Perawatan Dengan Menggunakan Psikoedukasi Berbasis Komputer Terhadap Klien $\begin{array}{lllll}\text { Depresi } & \text { Ringan. } & \text { l(1), } & \text { Re-74. } & \text { Retrieved }\end{array}$ http://download.portalgaruda.org/article.php?article=250187\&val=6686\&title=Manajemen Perawatan Dengan Menggunakan Psikoedukasi Berbasis Komputer Terhadap Klien Depresi Ringan

\section{Copyrights}

Copyright for this article is retained by the author(s), with first publication rights granted to the journal.

This is an open-access article distributed under the terms and conditions of the Creative Commons Attribution license (http://creativecommons.org/licenses/by/4.0/). 